\title{
Rapid Detection of the Fish-Pathogenic Bacterium Pasteurella piscicida by Polymerase Chain Reaction Targetting Nucleotide Sequences of the Species-Specific Plasmid pZP1.
}

\author{
Takashi Aoki*1, Daisuke Ikeda*2, Takayuki Katagiri and Ikuo Hirono \\ Laboratory of Genetics and Biochemistry, Department of Aquatic Sciences, Tokyo University of Fisheries, \\ Konan 4-5-7, Minato-ku, Tokyo 108, Japan
}

(Received October 24, 1996)

\begin{abstract}
A species-specific plasmid (pZP1) has been isolated from the fish-pathogenic bacterium Pasteurella piscicida. Two DNA fragments of PZP1 (PZP1-1 with 964 bp and PZP1-4 with 477 bp) were cloned from the plasmid pZP1. Two 20-mer primer sets, PZP1-1a and PZP1-1b, and PZP1-4a and PZP1-4b, were constructed according to the nucleotide sequences of fragments PZP1-1 and PZP1-4. A 484-bp DNA fragment was amplified from template DNA from 40 strains of $P$. piscicida by PCR using the PZP1-1a/1b primer set. The strains were isolated at different times of the year at different places in Japan and the USA. A 321-bp PCR product was amplified from all of the above strains of $P$. piscicida except strain ATCC17911 using the PZP1-4a/4b primer set. No such PCR products were obtained from template DNAs of Beneckea proteolytica, Photobacterium damsela, Ph. histaminum, Ph. leiognathi, 15 standard strains of Vibrio spp. or four fish pathogenic bacteria (Aeromonas hydrophila, A. salmonicida, Edwardsiella tarda and Enterococcus seriolicida). The PCR products were amplified with the PZP1-1a/1b primer set from DNA from the kidney of yellowtail (Seriola quinqueradiata) infected naturally with $P$. piscicida, but not from DNA from healthy yellowtail.
\end{abstract}

Key words: Pasteurella piscicida, PCR, diagnosis, plasmid

Control of bacterial infection in the intensive fishculture industry requires a rapid, sensitive and specific method for identifying and detecting fish-pathogenic bacteria. Standard culture techniques are timeconsuming, and immunological methods are not sufficiently sensitive and specific for detecting fish pathogens. In addition, these methods cannot easily detect fish-pathogenic bacteria from the early stage of infection.

The polymerase chain reaction (PCR) (Saiki et al., 1985; Mullis and Faloona, 1987) is an in vitro method of nucleic acid synthesis by which a particular segment of DNA can be specifically replicated. Species-specific primer sets for the identification and detection of fishpathogenic bacteria by PCR have been developed for many pathogens, including Aeromonas salmonicida (Miyata et al., 1995), Edwardsiella tarda (Aoki and

*1: Author to whom correspondence should be addressed. Tel: 03-5463-0556 / Fax: 03-5463-0690

*2: Present address: Laboratory of Aquatic Molecular Biology and Biotechnology, Division of Agriculture and Agricultural Life Sciences, Graduate School, The University of Tokyo, Bunkyo, Tokyo 113, Japan.
Hirono, 1995), Cytophaga psychrophila (Toyama et al., 1994), Renibacterium salmoninarum (Brown et al., 1994), Vibrio anguillarum (Hirono et al., 1996), and Vibrio trachuri (Iwamoto et al., 1995).

Pasteurella piscicida is the causative agent of pseudotuberculosis in yellowtail, Seriola quinqueradiata (Kimura and Kitao, 1971). Pseudotuberculosis is one of the most important causes of mortality in yellowtail. We developed a primer set for the amplification of a species-specific 629-bp DNA fragment (Pp1) from the chromosome of P. piscicida (Aoki et al., 1995). However, the same size PCR product was detected in some species of the genus Vibrio by PCR using this primer set under low-stringent PCR conditions.

Previously, we also found a species-specific plasmid, pZP1, of P. piscicida (Zhao and Aoki, 1992). In the present study, two primers were selected from the region of the species-specific fragment of pZP1. We demonstrate their use for the rapid identification and detection of $P$. piscicida by PCR. 


\section{Materials and Methods}

\section{Bacterial strains}

The bacterial strains used in this study are listed in Tables 1 and 2. Escherichia coli JM109 were cultured in $2 \times$ YT broth (1.6\% tryptone, $1.0 \%$ yeast extract, $0.5 \%$ $\mathrm{NaCl}$ ) at $37^{\circ} \mathrm{C}$ for $24 \mathrm{~h}$. All other strains were cultured in brain-heart-infusion (BHI) broth and BHI agar (Difco Laboratories, USA) containing $2 \% \mathrm{NaCl}$ at $25^{\circ} \mathrm{C}$ for $24 \mathrm{~h}$.

\section{DNA isolation}

Bacterial total DNA was isolated by a modification of the method described by Ausubel et al. (1987). Plasmid DNA was prepared as described by Sambrook et al. (1989). Concentration of the purified DNA was determined using the Gene Quant system (Pharmacia, Sweden). Total DNAs from $P$. piscicida were extracted by a boiling method (Aoki and Hirono, 1995).

\section{Subcloning of pZPI}

The $P$. piscicida-specific plasmid pZPI (Fig. 1) (Zhao and Aoki, 1992) was cloned into plasmid vector pUC19.
The cloned pZPI DNA was digested with HincII or with a combination of HincII and EcoRI. The DNA fragment digested with HincII was self-ligated by using a DNA Ligation Kit Ver. 2 (Takara, Japan). The DNA fragment digested with HincII and EcoRI was ligated with pUC119.

\section{Colony hybridization}

Horseradish peroxidase-labelled single-strand DNA probes were prepared using ECL direct nucleic acid labelling and detection systems (Amersham, UK) according to the manufacturer's instructions.

Colony hybridization was carried out by a modification of the method described by Grunstein and Hogness (1975). Bacterial colonies on BHI agar were picked up with a sterilized toothpick and fixed on a nylon membrane (Hybond $\mathrm{N}^{+}$, Amersham, UK). Duplex membranes were prepared and hybridized with the peroxidase-labeled DNA probe. Hybridization and washing conditions were as described in the ECL direct nucleic acid labelling and detection systems.

Table 1. Bacterial strains used in thi study

\begin{tabular}{|c|c|c|}
\hline Strains & & Source and references \\
\hline Pasteurella piscicida & see table 2 & \\
\hline Beneckea proteolytica & NCBC1326 & Aoki et al., 1989 \\
\hline Photobacterium damsela & ATCC33539 & Smith et al., 1991 \\
\hline Ph. histaminum & JCM8968 T & Okuzumi et al., 1994 \\
\hline Ph. leiognathi & ATCC25521 & Aoki et al., 1989 \\
\hline Vibrio alginolyticus & NCMB1903 & $"$ \\
\hline V. anguillarum & ATCC19264 & $"$ \\
\hline V. campbellii & ATCC 25920 & $"$ \\
\hline V. costicola & NCMB701 & $"$ \\
\hline V. diazotrophicus & ATCC33466 & $"$ \\
\hline$V$. fischeri & ATCC7744 & $"$ \\
\hline V. gazogenes & ATCC29988 & $"$ \\
\hline V. harveyi & ATCC14126 & $"$ \\
\hline$V$. hollisae & JCM01283 & $"$ \\
\hline V. natriegens & $\mathrm{CCM} 2575$ & $"$ \\
\hline V.nereis & ATCC25917 & $"$ \\
\hline V. ordalii & ATCC33509 & $"$ \\
\hline$V$. parahaemolyticus & ATCC17802 & $"$ \\
\hline V.pelagius & ATCC25916 & $"$ \\
\hline V. vulnificus & ATCC27562 & $"$ \\
\hline Aeromonas hydrophila & ATCC7966 & Popoff M., 1984 \\
\hline A. salmonicida & ATCC 14174 & Smith, I. W., 1963 \\
\hline Edwardsiella tarda & MZ8901 & in this study. \\
\hline Enterococcus seriolicida & NG8206 & in this study. \\
\hline Escherichia coli & Mos Blue carrying pMos Blue & Amersham, USA \\
\hline E. coli & JM109 carrying pUC19 & Sambrook et al., 1989 \\
\hline E. coli & JM109 carrying pUC119 & Sambrook et al., 1989 \\
\hline
\end{tabular}


Table 2. Amplification of species-specific DNA fragment from various strains of Pasteurella piscicida by PCR with primer sets of PZP1-1a/1b and PZP1-4a/4b

\begin{tabular}{|c|c|c|c|c|}
\hline \multirow{2}{*}{ Strains } & \multirow{2}{*}{ Source and reference } & \multicolumn{3}{|c|}{ amplification with primer } \\
\hline & & $\mathrm{PZP} 1-1 \mathrm{a} / 1 \mathrm{~b}$ & PZP1-4a/4b & Pp1 primers*1 \\
\hline ATCC 17911 & Snieszko et al. (1964) & $+* 2$ & - & + \\
\hline KP9016 & Kagoshima (1990) & + & + & + \\
\hline KP9038 & Kagoshima (1990) & + & + & + \\
\hline KP9406 & Kagoshima (1994) & + & + & + \\
\hline KP9409 & Kagoshima (1994) & + & + & + \\
\hline KP9411 & Kagoshima (1994) & + & + & + \\
\hline KP9422 & Kagoshima (1994) & + & + & + \\
\hline KP9432 & Kagoshima (1994) & + & + & + \\
\hline KP9445 & Kagoshima (1994) & + & + & + \\
\hline KP9464 & Kagoshima (1994) & + & + & + \\
\hline KP9435 & Kagoshima (1994) & + & + & + \\
\hline KP9433 & Kagoshima (1994) & + & + & + \\
\hline KР9483 & Kagoshima (1994) & + & + & + \\
\hline KP9511 & Kagoshima (1995) & + & + & + \\
\hline KP9550 & Kagoshima (1995) & + & + & + \\
\hline KР9578 & Kagoshima (1995) & + & + & + \\
\hline KP9579 & Kagoshima (1995) & + & + & + \\
\hline KP9580 & Kagoshima (1995) & + & + & + \\
\hline SP90-078 & Ehime (1990) & + & + & + \\
\hline SP90-043 & Ehime (1990) & + & + & + \\
\hline SP91-142 & Ehime (1991) & + & + & + \\
\hline SP91-041 & Ehime (1991) & + & + & + \\
\hline SP91-149 & Ehime (1991) & + & + & + \\
\hline SP91-278 & Ehime (1991) & + & + & + \\
\hline SP93-052 & Ehime (1993) & + & + & + \\
\hline SP93-041 & Ehime (1993) & + & + & + \\
\hline SP95-096 & Ehime (1995) & + & + & + \\
\hline SP95-098 & Ehime (1995) & + & + & + \\
\hline SP95-102 & Ehime (1995) & + & + & + \\
\hline SP95-103 & Ehime (1995) & + & + & + \\
\hline SP95-109 & Ehime (1995) & + & + & + \\
\hline NA90-09 & Nagasaki (1990) & + & + & + \\
\hline NA90-25 & Nagasaki (1990) & + & + & + \\
\hline NA90-29 & Nagasaki (1990) & + & + & + \\
\hline NA90-30 & Nagasaki (1990) & + & + & + \\
\hline NP91-10 & Nagasaki (1991) & + & + & + \\
\hline NP91-45 & Nagasaki (1991) & + & + & + \\
\hline $91-278$ & $\begin{array}{l}\text { USA (1991) } \\
\text { Supplied from Dr. P. Hawke }\end{array}$ & + & + & + \\
\hline $94-110$ & $\begin{array}{l}\text { USA (1994) } \\
\text { Supplied from Dr. P. Hawke }\end{array}$ & + & + & + \\
\hline $94-165$ & $\begin{array}{l}\text { USA (1994) } \\
\text { Supplied from Dr. P. Hawke }\end{array}$ & + & + & + \\
\hline
\end{tabular}

+: amplified, -: not amplified.

*1 Aoki et al., (1995)

*2 The molecular size of PCR product differed from that of other tested strains of $P$. piscicida.

\section{DNA Sequencing}

Dideoxy sequencing (Sanger et al., 1977) of the cloned DNA fragments was carried out using the Thermo Sequenase fluorescent-labelled primer cycle sequencing kit with 7-deaza-dGTP (Amersham, UK). Electrophoresis and data collection was performed on a DNA sequencer, Model 4000L (LI-COR, USA). 


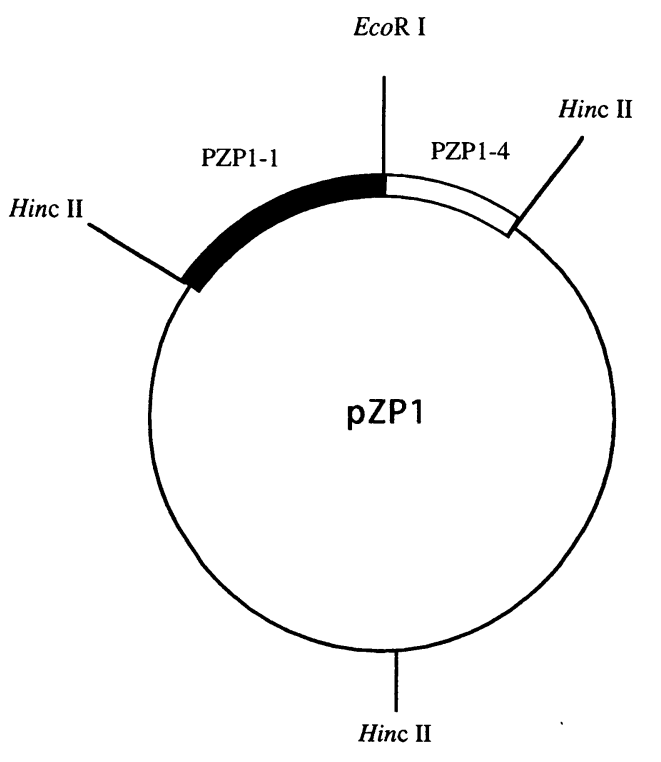

Fig. 1. Restriction map of the common plasmid pZP1 isolated from Pasteurella piscicida.

Black bar region (PZP1-1) was ligated into pUC19. White bar region (PZP1-4) was ligated into pUC119.

\section{Identification test using the synthesized primer sets}

Total DNAs from four strains of $P$. piscicida (ATCC 17911, KP 9038, SP 91-142 and 91-278 ), the abovementioned single strain of $B$. proteolytica, 3 strains of Photobacterium spp., 15 strains of Vibrio spp., and four species of fish-pathogenic bacteria (A. hydrophila, $A$. salmonicida, E. tarda and E. seriolicida) were prepared as template DNAs to examine the species specificity of our designed primer sets. PCR was carried out using 1 ng of template DNA, $0.2 \mathrm{mM}$ of dNTP mixture, $0.5 \mu \mathrm{M}$ of each primer, 0.5 unit of Ex Taq polymerase (Takara, Japan) and $2 \mu l$ of Ex Taq buffer, in a total volume of 20 $\mu l$. Following initial denaturation at $95^{\circ} \mathrm{C}$ for 30 to 120 s, 30 thermal cycles consisting of $30 \mathrm{~s}$ at $95^{\circ} \mathrm{C}$ to denature, $30 \mathrm{~s}$ at $58^{\circ} \mathrm{C}$ to anneal and $30 \mathrm{~s}$ at $72^{\circ} \mathrm{C}$ to extend were performed. The samples were post-heated at $72^{\circ} \mathrm{C}$ for 5 min after thermal cycling. The PCR products were mixed with 0.2 volumes of loading buffer $(0.25 \%$ bromophenol blue, $0.25 \%$ xylene cyanol FF, $30 \%$ glycerol) and electrophoresed on a $1.0 \%$ agarose gel. The gel was stained with ethidium bromide and visualized under UV light.

The PCR conditions for the primer set Pp1 were the same as the above conditions except for the annealing temperature, which was $62^{\circ} \mathrm{C}$. The primer set $\mathrm{Pp} 1$ is described by Aoki et al. (1995).

\section{Determination of PCR sensitivity}

The minimum amounts of $P$. piscicida DNA or $P$. piscicida cells that are needed to produce a PCR product using the PZP1-1a/1b and PZP1-4a/4b primer sets were determined. Extracted total DNA of $P$. piscicida SP91142 was diluted 10 times (from $1 \mathrm{ng} / \mu l$ to $100 \mathrm{ag} / \mu l$ ) and used for PCR. Pasteurella piscicida SP91-142 cells were diluted $10^{6}$ times (from $1 \times 10^{7}$ cells $/ \mathrm{ml}$ to $1 \times 10$ cells $/ \mathrm{m} l$ ) and $1 \mathrm{~m} l$ of the diluted cell suspension was boiled for $5 \mathrm{~min}$. Aliquots of the supernatants $(1 \mu \mathrm{l})$ were used for PCR templates. Secondary PCR was carried out using $1 \mu l$ of the first PCR product as a template.

\section{Detection of $P$. piscicida from naturally infected fish}

Five yellowtail, with a mean body weight of $61 \mathrm{~g}$ and whose head kidneys and spleens had white spot tubers, were collected from fish farms in Ehime in 1996 Another five fish without white spot tubers were used as a negative control. Template DNAs were extracted from the kidney homogenates of these fish. At the same time, the bacterial isolation from the kidneys of both groups was attempted using BHI agar containing $2 \%$ $\mathrm{NaCl}$.

\section{Results}

A HincII-digested DNA fragment of pZP1 (designated PZP1-1) hybridized with tested 14 strains of $P$. piscicida (ATCC 17911, KP 9038, SP 91-142, 91-278, KP 9511, KP 9550, KP 9578, KP 9579, KP 9580, SP 95-096, SP 95-098, SP 95-102, SP 95-103 and SP 95-109) but did not hybridize with the single strain of $B$. proteolytica, 3 strains of Photobacterium or 15 strains of Vibrio spp.

A HincII- and EcoRI- digested DNA fragment (designated PZP1-4) hybridized with all of the tested strains of $P$. piscicida except ATCC17911, but did not hybridize with the single strain of $B$. proteolytica, 3 strains of Photobacterium or 15 strains of Vibrio spp.

The nucleotide sequences of PZP1-1 (947 bp) and PZP1-4 (477 bp) are shown in Figs. 2 and 3, respectively. The forward primer ( PZP1-1a) and the reverse primer (PZP1-1b) were the 20-mers 5'-GCCCCCATTCCAGTCACACA-3' and 5'-TCCCTAAGCACACCGACAGG3', respectively, both constructed from the nucleotide sequences of PZP1-1 (Fig. 2). The other primers were based on the nucleotide sequence of PZP1-4. The forward primer (PZP1-4a) and the reverse primer (PZP1- 
gtcgacAtGA CTTTACACAC AATCGCCTAA TTAGAATGA ATCGCAGAAA GATACGCTCG 60 Hinc II site CGCTCAATAA GATGTTTATA TGATTTTGAA ATAGAAAAGC CGAGCAAAAA GGAAGTCGCC 120 AAAGGTCAGC TTGATTGCCT TTCGGCTGCG CCCCCCTACC CAATTTCAGC TAAATTTTAG 180 CGAAATCGAG TATCTTTTTG GTCGCATCAG ATCGGGGTTT GTCTCTTACC CTTTCGGGCG 240 TTCCTGCGCT GTGTGTAAAG GCTTTCGCCC CCATTCCAGT CACACAATCT TCGAGGTTAT 300 PZP1-1a TATCATTAAG TCGCAGCCCC AACCTGAACG CTATAGTTGG GCGACACATT ACGTCATTTT 360 CCCGAAGACC TTTACCTCCA CCTATGGAAT ATCCCTTGAT CGGTGGTGAT GCGCATCGCT 420 CTATCCAAAA CATCTTGATC CAAATAGAgt GCAGGAGTAC TTGAAGTGCT TCTATGAATT 480 GTCTATCATG AAAGGACTTA ACGAGCTTCG AAAATCGTCT TAAGTATTCC GAATAAACCA 540 GCACGCCAAT GCTGGTTTTT TCACATCTGG ACAAAGATAC TACTCTGCCA CTCAAAATAA 600 CTCAAGCACA ACCTCTCACC CATCAATCAA ACCGCAAAAA CAGAATAATC TAAGTAAAAC 660 ATAACCTTAT TATACTTTTT TCTTTAATAT ATCATGCTAT CTCGTAGAGA TTTTAGgGTT 720 TTAGGGAAAA TCCCTAAGCA CACCGACAGG GCACGACGAT TAAACAAACG AGGAACGAGT 780 PZP1-1b

TTGTATACAA TCGGTAGCGT GCCTGTATAC GTCGGTAGCG TGCCTATATT AATTAAGCTC 840 TAAAGTGTGA CCGCCCCCAC AGATTCACCA CAAATTCCCC AAAAGTTCAC CTAGAAATCA 900 CCACACATTC CCCATTTCAA TAGTTGATAT TGCAAATAgT TCCCCATAAA ATCACTACga 960 attc

Fig. 2. The nucleotide sequence of PZP1-1 cloned from pZP1 of Pasteurella piscicida. The nucleotide sequences of the forward and reverse primers are underlined.

gaattcACCA TAAATTCCCC ATGAGTTCAC CAAGGACAAC GAAATGAACG AAGAAGAGTT 60 ECOR I site AAAAACCTTA TTATCACCTT TTATTAGAGA CATTAATGGT GGTGTTTTAA GTAATTTAGC 120 CTGTATCAAA ACACATGCTG AATTACTGTT ATCACTACGT GCAAAAGGTG TTCCTTTAAG 180 GCTGATTGTT GAATTATCAG GAACTAGTTA TAGCAATAAA ACCTTTAGTA AAAAGCTAAG 240 TGGCTTTAAA AAAAGCCTAG CTATTAAACC AAAAGAAATG CCAACAGCAG AAAAAGGGAC 300 TTTTTCAAAA GCGGCTTTGA GTTCTTCTAA ACCAGAAACT AAACAGGAAC CGATTAAGCC 360 TGACAACAAA GAAGAATCGg ACGAATtAGA ATATAgCTTA GATGATTGGA TTAGTAACAC 420 TCGCCTAAGT AAAGGAAACA TTCGCCTCTA TCGACAAGGA GAGAAAGACG Gqttgac 477 PZP1-4b Hinc II site

Fig. 3. The nucleotide sequence of PZP1-4 cloned from pZP1 of Pasteurella piscicida. The nucleotide sequences of the forward and reverse primers are underlined. 
4b) were the 20-mers 5'-CTACGTGCAAAAGGTGTTCC-3' and 5'-AAGGAGAGAAAGACGGGTTG-3', respectively (Fig. 3).

A specific DNA fragment having a length of $484 \mathrm{bp}$ was amplified by PCR with the PZP1-1a/1b primer pair from 4 strains of $P$. piscicida, although the amplified DNA from ATCC17911 was larger than that of the other strains of $P$. piscicida (Fig. 4). A 484-bp PCR product was subsequently obtained from boiled-extracted DNA from 36 strains of $P$. piscicida using the PZP1-1a/1b primer pair (Table 2). No fragment was amplified from the above-mentioned 15 strains of Vibrio spp., 3 strains of Photobacterium, 1 strain of B. proteolytica or 4 strains of fish-pathogenic bacteria (Fig. 4).

On the other hand, a 321-bp PCR product with primers PZP1-4a/4b was obtained from 3 strains of $P$. piscicida but not from strain ATCC17911 (Fig. 5). The PZP1$4 \mathrm{a} / 4 \mathrm{~b}$ primer pair also amplified products from all other strains of $P$. piscicida (Table 2). A similar sized DNA fragment was amplified from $B$. proteolytica, $P h$. leiognathi, $V$. anguillarum, $V$. diazotrophicus, and $V$. hollisae (Fig. 5). The amounts of PCR products from B. proteolytica, Ph. leiognathi, V. anguillarum, V. diazotrophicus, and $V$. hollisae were lower than that from
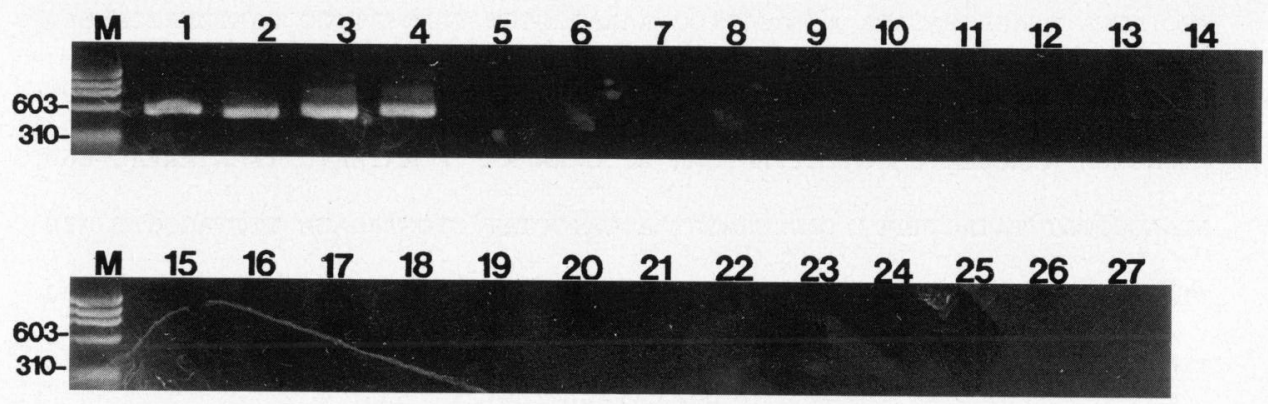

Fig. 4. Agarose gel electrophoresis of PCR products using the $P$. piscicida-specific primer set, PZP1-1a and $1 \mathrm{~b}$.

Lanes: M, $\phi$ X 174-DNA digested with HaeIII as a molecular size marker; 1, Pasteurella piscicida ATCC17911; 2, P. piscicida KP9038; 3, P. piscicida SP91-142; 4, P. piscicida SP91-278; 5, Photobacterium damsela ATCC33539; 6, Ph. histaminum JCM8968; 7, Ph. leiognathi ATCC25521; 8, Beneckea proteolytica NCMB1903; 9, Vibrio alginolyticus NCMB1903; 10, V. anguillarum ATCC19264; 11, V. campbellii ATCC25920; 12, V. costicolus NCMB701; 13, V. diazotrophicus ATCC33466; 14, V. fischeri ATCC7744; 15, V. gazogenes ATCC29988; 16, V. harveyi ATCC14126; 17, V. hollisae JCM01283; 18, V. natriegens CCM2575; 19, V. nereis ATCC25917; 20, V. ordalii ATCC33509; 21 V. parahaemolyticus ATCC17802; 22, V. plagius ATCC25916; 23 V. vulnificus ATCC27562; 24, Aeromonas hydrophila ATCC7976; 25, A. salmonicida ATCC14174; 26, Edwardsiella tarda MZ8901; 27, Enterococcus seriolicida NG8206.
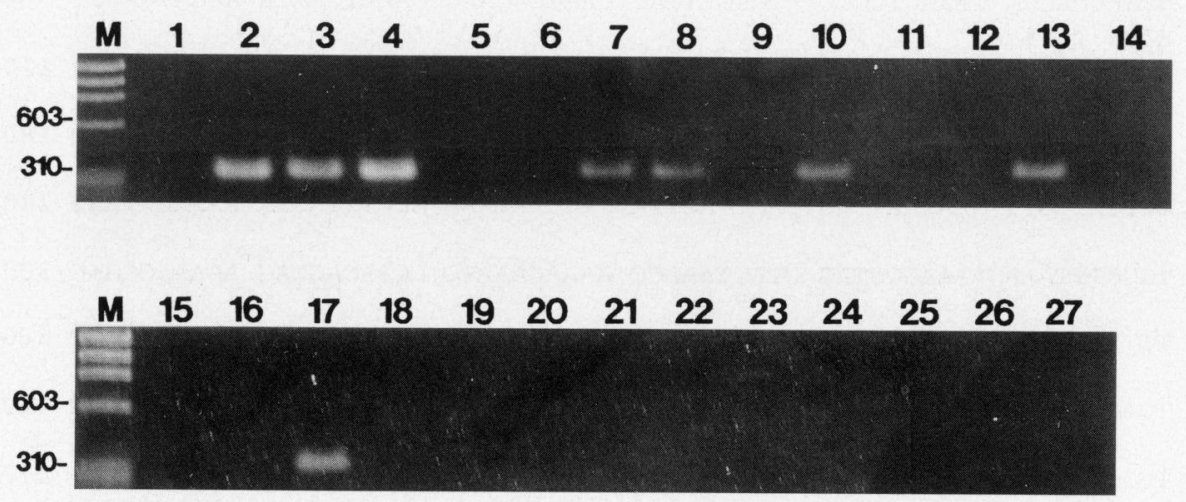

Fig. 5. Agarose gel electrophoresis of PCR products using the P. piscicida-specific primer set, PZP1-4a and 4b. Lanes: M, $\phi$ X 174-DNA digested with HaeIII as a molecular size marker; numbers in lanes 1-27 refer to strains shown in Fig. 4 . 
P. piscicida (Fig. 5).

A 629-bp PCR product was detected from 4 strains of $P$. piscicida and Ph. damsela when using the primer set Pp1 (Fig. 6). In addition, when PCR was performed with an annealing temperature of $58^{\circ} \mathrm{C}$, the PCR product was detected in 4 strains of $P$. piscicida, the single strain of $B$. proteolytica, 3 strains of Photobacterium spp., and 15 strains of Vibrio spp. (data not shown).

The minimum amount of DNA detectable in the first PCR using the PZP1-1a/1b and PZP1-4a/4b primer sets was $100 \mathrm{fg}$. However, using the secondary PCR method, the minimum amount of DNA was $10 \mathrm{fg}$ (data not shown). The products obtained from the PZP1-1a/ $1 \mathrm{~b}$ and $\mathrm{PZP} 1-4 \mathrm{a} / 4 \mathrm{~b}$ primer pairs required a minimum of
$10^{3}$ bacterial cells $/ \mathrm{ml}$ in the first PCR, but only $10^{2}$ cells/ $\mathrm{ml}$ in the second PCR (data not shown).

Two DNA fragments having lengths of 484 and 530 bp were obtained from DNA extracted from kidney homogenates of all 5 yellowtail in which $P$. piscicida was detected by a standard culture method (Fig. 7, lanes 3 to 7 ). On the other hand, these specific fragments were not detected in five apparently healthy yellowtail in which $P$. piscicida was not detected by a standard culture method (Fig. 7, lanes 8 to 12).
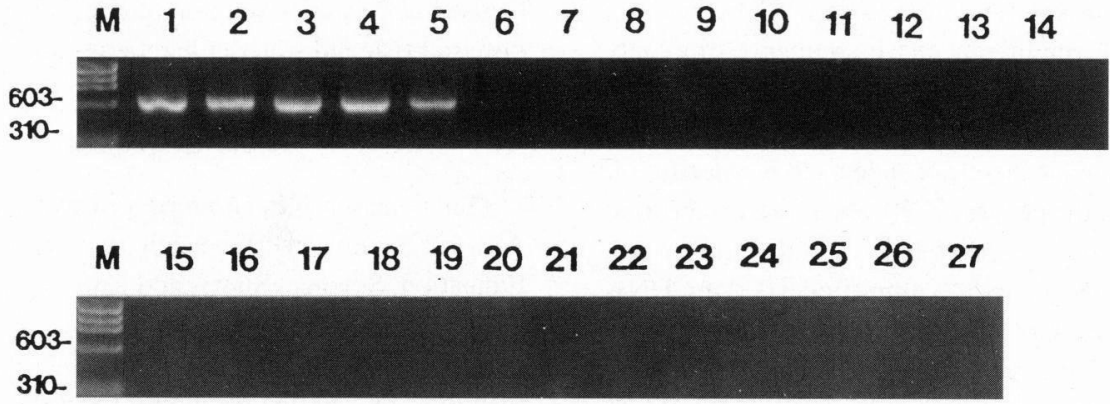

Fig. 6. Agarose gel electrophoresis of PCR products using the Pp1 primers set.

Lanes: M, $\phi$ X 174-DNA digested with HaeIII as a molecular size marker; numbers in lanes 1-27 refer to strains shown in Fig. 4.

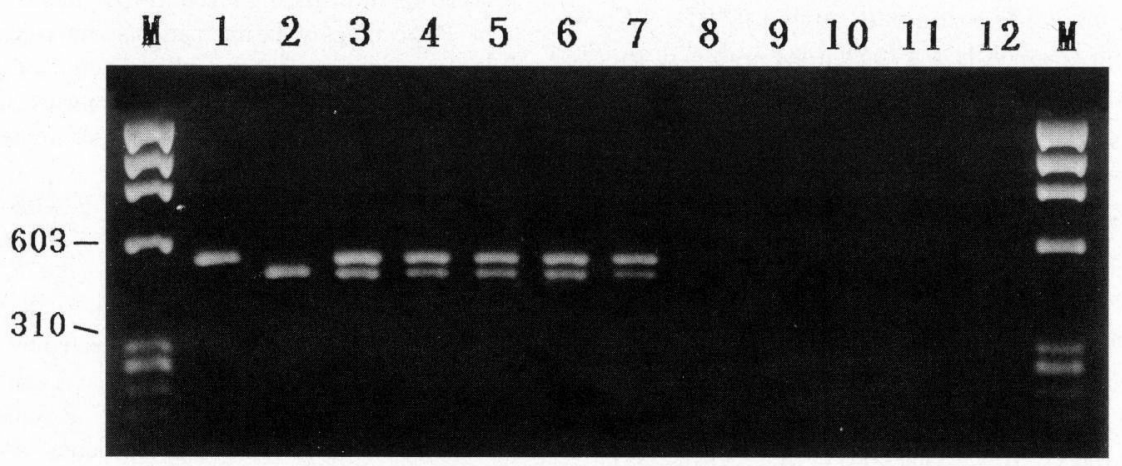

Fig. 7. Detection of Pasteurella piscicida from naturally infected yellowtail and apparently healthy yellowtail by PCR with the PZP1-1a/1b primer set.

Lanes: M, $\phi$ X 174-DNA digested with HaeIII as a molecular size marker; 1, strain ATCC17911; 2, strain KP9038; 3 to 7 , naturally infected yellowtail; 8 to 12 , apparently healthy yellowtail which were not infected with $P$. piscicida cells. 


\section{Discussion}

Gauthier et al. (1995) proposed reclassifying Pasteurella piscicida as a new species, Photobacterium damsela subspecies piscicida, based on its $16 \mathrm{~S}$ rRNA sequences. Previously, we reported a primer set for the amplification of a 629-bp DNA fragment (Pp1) from the chromosome of $P$. piscicida (Aoki et al., 1995). In the present study, however, this primer set amplified the same size PCR product from $P h$. damsela even under the high-stringent PCR condition(Fig. 6). In addition, under the low-stringent PCR condition, the same size PCR product was amplified from several species of the genus Vibrio. In this study, we tried to amplify products by PCR using our PZP1-1a/1b and PZP1-4a/4b primer sets and template DNAs from $B$. proteolytica, Photobacterium spp. and Vibrio spp. The primers PZP1-1a and 1b amplified a 484-bp sequence from only $P$. piscicida and did not amplify a DNA fragment of any size from B. proteolytica, Photobacterium spp., or Vibrio spp. This sequence therefore appears to be specific for $P$. piscicida and the primers PZP1-1a and $1 \mathrm{~b}$ can be used for identification of $P$. piscicida. On the other hand, the primers PZP1-4a and 4b amplified a 321-bp DNA fragment from each of the tested strains of $P$. piscicida except ATCC17911, and also amplified a similar sized DNA fragment from B. proteolytica, Ph. leiognathi, $V$. anguillarum, V. diazotrophicus, and V. hollisae (Fig. 5). This result suggests that $B$. proteolytica, Ph. leiognathi, $V$. anguillarum, $V$. diazotrophicus, and V. hollisae possess a sequence homologous to the primers PZP1-4a and $4 \mathrm{~b}$.

Zhao and Aoki (1992) reported that all Japanese isolates of $P$. piscicida examined carried pZP1. We have found that strain ATCC17911 does not carry this plasmid(Zhao and Aoki, 1992). When using the PZP11a/1b primer set, the amplified DNA from ATCC17911 was larger in size than that from other strains of $P$. piscicida including 3 strains isolated in the USA (Fig. 4, Table 2). We cloned the PCR products from ATCC17911 to the pMOSBlue T-vector kit (Amersham, USA) and determined its nucleotide sequence. The length of the larger sequence from ATCC17911 was 530 bp. Strain ATEC17911 was isolated from white perch in the 1963 in the U. S. A. (Snieszko et al., 1964). It is thought that a partial region of pZP1 might have become integrated into the chromosomal DNA of $P$. piscicida ATCC17911. In an experiment to see if $P$. piscicida could be detected in naturally infected yellowtail, we obtained two PCR products from $P$. piscicida -infected fish using the PZP1-1a /1b primer set. One was 484 bp and the other was $530 \mathrm{bp}$ in length (Fig. 7). The 484-bp sequence was recognized as part of PZP1 and the 530-bp sequence was recognized as part of the chromosomal DNA. Further work is needed to explain this result.

In the experiment to determine the minimum number of bacterial cells for a PCR product, a PCR product was obtained from the 2 nd PCR using 0.1 cell in the reaction. This indicates that the copy number of pZP1 is greater than 10 copies per one cell and suggests that the copy number of the PCR target region is important for the sensitive detection of fish infected with bacteria.

PCR amplification by $P$. piscicida-specific primers was able to detect diseased fish infected with $P$. piscicida. The specific $P$. piscicida primers PZP1-1a and $1 \mathrm{~b}$ could be used widely for detection of etiological agents from diseased fish and water at hatcheries and farms.

\section{Acknowledgements}

This research was supported in part by a Grant-inAid for Scientific Research from the Ministry of Education, Science, Sports and Culture of Japan. We are grateful to Kagoshima Prefectural Fisheries Experimental Station, Nagasaki Prefectural Institute of Fisheries, and Ehime Prefectural Fish Disease Control Center for kindly providing strains of Pasteurella piscicida.

\section{References}

Aoki, T. and I. Hirono (1995): Detection of fish-pathogenic bacteria, Edwardsiella tarda, by polymerase chain reaction. In "Proceedings of the international symposium on biotechnology applications in aquaculture" (ed. by C.-M. Kuo, J.-L. Wu and P.-P. Huang). Asian Fisheries Society Special Publication No. 10. Asian Fisheries Society, Manila, pp. 135-146.

Aoki, T., I. Hirono, T. D. Castro and T. Kitao (1989): Rapid identification of Vibrio anguillarum by colony hybridization. J. Appl. Ichthyol., 5, 67-73.

Aoki, T., I. Hirono and A. Hayashi (1995): The fish-pathogenic bacterium Pasteurella piscicida detected by the polymerase chain reaction (PCR). In "Diseases in Asian aquaculture II" (ed. by M. Shariff, J. R. Arthur and R. P. Subasinghe). Fish Health Section, Asian Fisheries Society, Manila, pp. 347353.

Ausubel, F. M., R. Brent, R. E. Kingston, D. D. Moore, J. G. Seidman, J. A. Smith and K. Struhl (1987): Preparation of genomic DNA from bacteria, In "Current protocols in molecular biology, contents of supplement" John Wiley \& Sons Inc. New York pp. 2.4.1.-2.4.5 
Brown, L. L., G. K. Iwama, T. P. T. Evelyn, W. S. Nelson and R. P. Levine (1994): Use of the polymerase chain reaction (PCR) to detect DNA from Renibacterium salmoninarum within individual salmonid eggs. Dis. Aquat. Org., 18, 165171.

Gauthier, G., B. Lafay, R. Ruimy, V. Breittmayer, J. L. Nicolas, M. Gauthier and R. Christen (1995): Small-subunit rRNA sequences and whole DNA relatedness concur for the reassignment of Pasteurella piscicida (Snieszko et al.) Jansen and Surgalla to the genus Photobacterium as Photobacterium damsela subsp. piscicida comb. nov. Int. J. Syst. Bacteriol., 45, 139-144.

Grunstein, M. and D. S. Hogness. (1975): Colony hybridization, a method for the isolation of cloned DNAs that contain a specific gene. Proc. Natl. Acad. Sci. USA., 72, 3961-3965.

Hirono, I., T. Masuda and T. Aoki (1996): Cloning and detection of the hemolysin gene of Vibrio anguillarum. Microb. Pathogen., 21, 173-182.

Iwamoto, Y., Y. Suzuki, A. Kurita, Y. Watanabe, T. Shimizu, H. Ohgami and Y. Yanagihara (1995): Rapid and sensitive PCR detection of Vibrio trachuri pathogenic to Japanese horse mackerel (Trachurus japonicus). Microb. Immunol., 39, 1003-1006.

Kimura, M. and T. Kitao (1971) : On the etiological agent of bacterial tuberculosis of Seriola. Fish Pathol., 6, 8-14.

Miyata, M., V. Inglis and T. Aoki (1995): Rapid identification of Aeromonas salmonicida subspecies salmonicida by the polymerase chain reaction. Aquaculture, 141, 13-24.

Mullis, K. B. and F. A. Faloona (1987): Specific synthesis of DNA in vitro via a polymerase-catalyzed chain reaction. In "Methods in enzymology," Vol. 155 (ed. by R. Wu).
Academic Press, Inc. San Diego, pp. 335-350.

Okuzumi, M., A. Hirahashi, T. Kobayashi and T. Fujii (1994): Photobacterium histaminum sp. nov., a histamine-producing marine bacterium. Int. J. Syst. Bacteriol., 44, 631-636.

Popoff, M. (1984): Genus III. Aeromonas Kluyver and Van Niel 1936, 389 A $^{\mathrm{L}}$. Bergy's Manual of Systematic Bacteriology, Vol. 1. (ed. by N. R. Krieg and J. G. Holt). Williams \& Wilkins, Baltimore/London, pp. 545-548.

Saiki, R. K., S. Scharf, F. Faloona, K. B. Mullis, G. T. Horn, H. A. Erlich and N. Arnheim (1985): Enzymatic amplification of $\beta$-globin genomic sequences and restriction site analysis for diagnosis of sickle cell anemia. Science, 230, 1350 1354.

Sambrook, J., E. F. Fritsch and T. Maniatis (1989): Molecular cloning, a laboratory manual. Cold Spring Harbor Laboratory (2nd ed.), Cold Spring Harbor, New York.

Sanger, F., S. Niklen and A. R. Coulson (1977): DNA sequencing with chain-terminating inhibitors. Proc. Natl. Acad. Sci. USA., 74, 5463-5467.

Smith, I. W. (1963): The classification of "Bacterium salmonicida”. J. Gen. Microbiol., 33, 263-274.

Snieszko, S. F., G. L. Bullock, E. Hollis and J. G. Boone (1964): Pasteurella sp. from an epizootic of white perch (Roccus americanus) in Chesapeake Bay tidewater areas. $J$. Bacteriol., 88, 1814-1815.

Toyama, T., K. Kita-Tsukamoto and H. Wakabayashi (1994): Identification of Cytophaga psychrophila by PCR targeted 16S ribosomal RNA. Fish Pathol., 29, 271-275.

Zhao, J. and T. Aoki (1992): Plasmid profile analysis of Pasteurella piscicida and use of a plasmid DNA probe to identify the species. J. Aquat. Anim. Health, 4, 198-202. 